\title{
Over view of Septoria Diseases on Different Crops and its Management
}

\author{
Siddhartha Das*, Sudeepta Pattanayak and Boddepalli Bhargavi
}

Department of Plant Pathology, MS Swaminathan School of Agriculture, Centurion University of Technology and Management, Paralakhemundi, Odisha, India

"Corresponding author: siddhartha.das10@gmail.com (ORCID ID: 0000-0002-7482-2555)

Paper No. 858

Received: 25-03-2020

Revised: $18-07-2020$

Accepted: 24-08-2020

\begin{abstract}
Septoria is one of the major emerging pathogen of diverse plant families and has been reported from all over the world. It is the one of the major foliar disease which infects total shoot system and growing stage of plants (mostly Solanaceaceous crops). However, important fungal disease such as Septoria leaf spot caused by the fungal pathogen Septoria lycopersici is well known and not only restricted in Solanaceae. This fungal pathogen spreads rapidly and effected in any stage of development which ultimately causes quick defoliation and weakening of infecting part, rendering them unable to bear fruit tends to maturity. At the initial stage of infection symptoms appear as circular and angular lesions most commonly found on the older, lower leaves of the plant. The lesions contain pycnidia in the centre of spot in leaves to identify the pathogen of this region. This pycnidia are fruiting body of the fungus. When the lesions are more numerous often the leaves turn yellow, then brown shrivel up and eventually drooping of plant altogether, this fungal spores spread to healthy leaves by windblown, rain splashes, through irrigated water, mechanical transmission and through the activities of insects such as aphids, beetles etc. Septoria become more severe during warm, wet, humid periods and develops within four to five days from the date of transmission. In favorable time Septoria infects various cultivated and non cultivated crops but with the coming of unfavorable condition it retains in plant debris or body of secondary host round the season.

\section{Highlights}

( Septoria turned to be one of the major emerging pathogen under change in climatic condition with widespread variability.

0 Disease severity of the pathogen among both cultivated and non-cultivated crops ranged between $35-65 \%$ and turned to be a serious threat for future.

- Complex adoptability with cosmopolitan nature makes the pathogen more vigorous one by targeting new susceptible hosts and coupling with increased viability within its infection cycle.
\end{abstract}

Keywords: Septoria, emerging, host, pycnidia, management

Septoria leaf spot is caused by fungal pathogen Septoria lycopersici. Now a day, it is the one of the serious threat to all classes of farming communities. Even non-cultivated crops are also infected. The causal pathogen infects foliages with results to defoliation and retard the crop yield. In recent years, fungi are one of the serious factors causing severe infection and yield loss threatening the global food security (Chakraborty and Newton 2011; Fisher et al. 2012). Septoria can infect the canopy region of the plant where leaves become yellow and browning. Infection pattern consecutively starts from lower leaves and then to younger leaves. Low temperature, warm and humid conditions helps in pathogenic progress. Splashing of rain, windblown, mechanical transmissions are the mode

How to cite this article: Das, S., Pattanayak, S. and Bhargavi, B. (2020). Over view of Septoria Diseases on Different Crops and its Management. IJAEB, 13(3): 351-370.

Source of Support: None; Conflict of Interest: None 
of transmission of pathogen. After harvesting of the plants from the fields the pathogens remain alive in plant debris upto period of two years. The fugal pathogen exists as many species that infect not only on a particular host plant but also some plants act as an alternative host. It is found that pathogen survival and spreads turned low when relative humidity is low. Additionally dry foliage will help to control the disease. Pathogenicity partly or completely depends on the role of environmental parameters. According to environmental conditions the pathogen changes its morphotypes. Pycnidial appearance is clearly visible on the infected leaf surface under microscope. Spores are released through the central openings of infected leaves. Total yield losses caused by pathogen all over world are estimated at 9 million tons as per Kovalenko (1976). Zymoseptoria tritici the causal pathogen of Septoria tritici blotch (STB) is turned to be a major threat for wheat on worldwide basis (Savary et al. 2019). Now a day the best solution to eradicate the disease is considering only choice of chemical methods, like regular spraying of fungicides where necessary to control the disease dispersal and severity. Strobilurins, chlorothalonil, copper oxychloride etc are the major group of chemicals used against this pathogen attack. Application of mancozeb, maneb and some copper containing fungicides such as (Bordeaux mixture, copper hydroxide copper oxychloride sulfate) are act as most effective to control this pathogen.

In 1990, the triazoles were become sensitive to reduction of Septoria. For past few sensitivity of aforesaid chemicals found to be satisfactory against Septoria diseases. In the present days the pathogen shows fungicidal resistance against different agrochemicals for his complex, adoptive, mutative nature. For the current perspective, it is very much needful to prevent this type of pathogenic resistance by maintaining good practices using of resistant varieties and planting the seed dressing fungicides. Using of beneficial antagonists in the field reduce the effect of pathogen, simultaneously competes with the pathogens for food and nutrients. These kinds of micro organisms reduce the spore dispersal from infected plants to healthy plants. But still now no sufficient information is publicly available. And maintain proper crop rotation, and make field is in proper conditions which are free from debris by practicing these methods can prevent the disease severity. Prevention is the best method for managing the risk of development of disease. This fungal pathogen show very wide host range. Maintain good practices can control the disease efficiently. Practicing of integrated disease and pest management strategies (IDM and IPM) are helpful to control the disease infestation. Removal of diseased and contaminated weeds from the field or use appropriate organic herbicide to collect all the weeds and debris bury them. Plastic mulching operation in the field can reduce splashing of soil apply mulch to the field after soil was warmed. When the disease is in initial stage application of regular based treatment with fungicidal chemicals (7 to 14 days' intervals) throughout the season is found to be effective.

\section{Historical perspectives}

Septoria sp. again re-classified in many species and emerged through many new strains which showed pathogenicity to diverse hosts through different trend lines. The most destructive fungal pathogen Septoria is the telemorph of Mycosphaerella, again under Mycosphaerella sp. some species are re-classified and act as telemorph of Phaeosphaeria. These fungi infect different hosts which showed specialized pattern. Within the same individual species it has its own alternate hosts which act as primary inoculums to transmit the disease. Septoria tritici, is the telemorph of Mycosphaerella graminicola, and Stagonospora nodorum, cause frequent and severe disease on most cultivated and non-cultivated crops. According to the researchers, Septoria is one of the largest genera of plant- pathogenic fungi showing a range of disease symptoms including spots in agricultural crops (Holliday, 1989; Priest, 2006). In 1922 Weber, isolates Septoria tritici from Triticum aestivum, Secale cereal and Poa pratensis. The infection pattern and pathogenic nature to that hosts are very unique. In 1950, Sprauge states that Septoria tritici pathogenicity is not only restricted on wheat but on several grasses as well. In the year 1957, Hilu and Bever, suggested that Septoria tritici stayed over winters on alternate hosts particularly on wild grasses. Infected plants, plant debris weeds are the source of inoculums which transmit the disease year after year from which the conidia are disseminated mainly by rain splashes (Tokesh and Carvalho 
1980). Scientist revealed in different times about emergence, dispersal, host range, morphology, pathogenic characters and management of Septoria which are useful information to control the disease in initial condition.

\section{Study of host diversity}

Septoria sp. is specialized fungal pathogen which infects various hosts with a wide a host range among which some are well-known and some are still not reported. Two major important susceptible host crops are tomato (Lycopersicon esculentum) and marigold (Tagetes erecta L.) in India (Fig. 1 and 2). In low temperature condition Septoria infects various hosts very rapidly and cause damage to crops. Septoria infects susceptible host crop's foliage by entering through stomata, defoliate the crop canopy where leaves turn brown colour with reduced carbohydrate content and retard the yield. This devastating pathogen remains alive in the plant debris about 2 years post harvest situation. Septoria tritici isolates from triticum aestivum, secale cerale and poa pratensas, each of which was pathogenic on its own host but not on the other cereals or wild grasses tested by Weber in 1922. Additionally about 27 species/varieties of cereals and certain wild grasses were tested by Weber in the inoculation experiments under control conditions. It is mostly seen in the wheat growing areas of the country. The symptoms mainly observed on the petioles, leaf sheaths, midvein of leaves light green to yellow spots after 10 days of infection and pycnidia appear on center of spots which are mostly tan yellowish to brown and it is appeared after 12-15 days. The pycnidia colour varies from species to species. Septoria passerinii, fungal pathogen is isolated from Hordeum vulgare in the locality of khuzestin and its initial disease symptoms were pale brown, hologenous elongate lesions on the upper and lower leaf surfaces and the leaf sheaths (Shirin et al. 2009). After 20 days of infection dark brown to black pycnidia is formed. This species specially causes compound lesions. Another isolate of Septoria sp. isolated from Aegilops tauschiicosson which act as versatile pathogen of this species, in Golestan region (Shirin et al. 2009). This Septoria species was not even pathogenic on other Aegilops species. Here the nature of Septoria $s p$. is host specific. The disease symptoms were brown to necrotic lesions after 2 months of infection.
This pathogen mainly infects the canopy region of the plant. The pycnidia were dark brown usually solitary, sometimes aggregating. Avena ludoviciana Durieu, is another susceptible host of Septoria calamagrostidis, is found in the areas of Golestan and Khuzestan in Iran. The disease symptoms are yellowish to pale brown lesions and the pycnidia is in dark brown to black colour. This species required special environmental condition to infect its host. Two important hosts of Septoria halophila are H. glaucum Steud. and H. geniculatum found in Khuzstan and Ilam, Iran respectively (Shirin et al. 2009). In this case Septoria is host specific. Symptoms are after 12 to 14 days of infection dark brown lesions consistency with pale and buff and the fruiting bodies (pycnidia) at post infection stages on leaves, which are heavily mottled it is mostly seen in lower regions. Lolium loliaceumthe is another important host of Septoria sp. Symptomatic characterization expressed with pale-brown lesions and the pycnidia is in brown to black in colour.

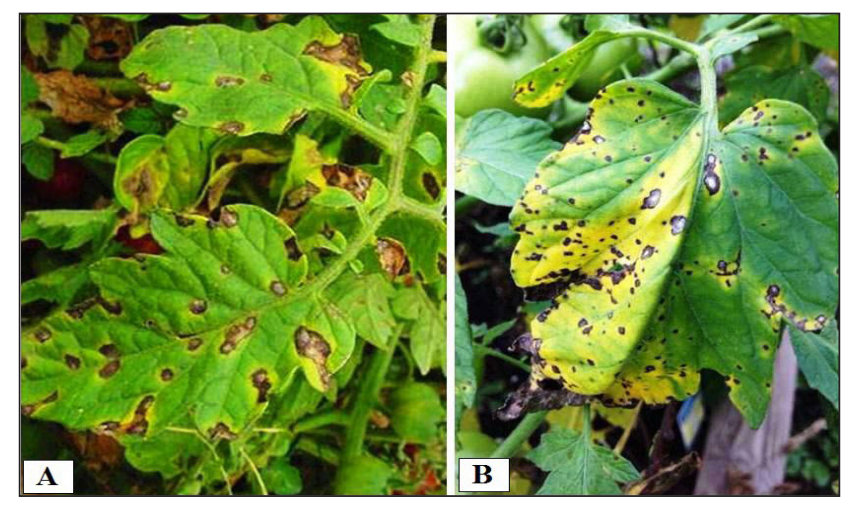

Fig. 1: Septoria leaf spot on tomato (Lycopersicon esculentum)

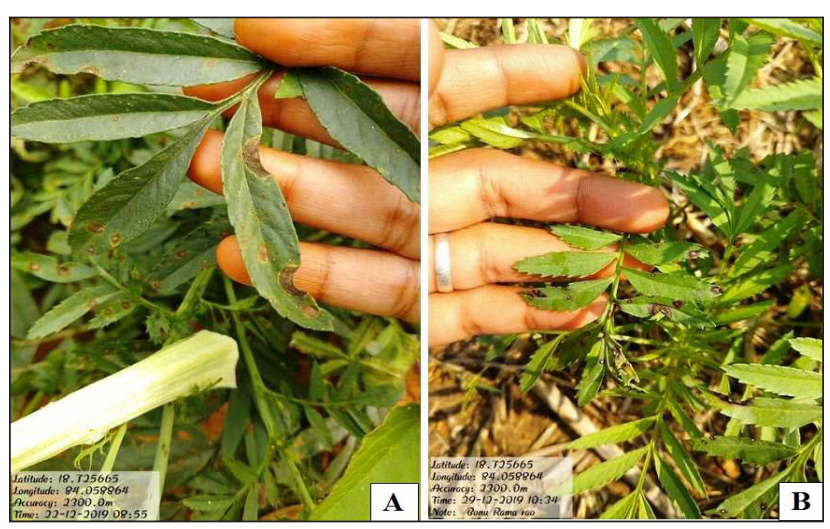

Fig. 2: Septoria leaf spot on marigold (Tagetes erecta L.)

\section{Morphological and cultural variability}

Morphological variability is clearly found in 
different structures of the same species or different structures of diverse species. Variability observed in pycnidial size, pycnidia spores and conidial septa, shape and size, ostiole size among isolates to isolates or species to species. These hyphae are often partitioned by cross walls called septa. The septate hyphae are having individual cells by internal walls which having centre pore. Septoria sp. is characterized by smooth-walled multi-septate conidia, pycnidial conidiomata, filliform, hyaline. Among all species the morphological characters of Septoria triseti are varies under the morphometric specification as conidia length $(19-40 \mu \mathrm{m})$; width $(1-1.5 \mu \mathrm{m})$; septa (0-3); pycnidia diameter (50-90 $\mu \mathrm{m})$; spore length $(35-56 \mu \mathrm{m})$; number of septa (2-7) in one spore. These morphometric characters are differs in individual species and related species of same ancestral origin of Septoria. In the Septoria sp.1 (host - Aegilops tauschii) the morphometric specification specified as conidial length (19-40 $\mu \mathrm{m})$; width (1-1.5 $\mu \mathrm{m})$; septa (0-3); pycnidia is in dark brown, solitary and sometimes aggregating. In Septoria sp. 2 (Host - Lolium loliaceum) the length of conidia varies $(20-46 \mu \mathrm{m})$; width $(1-1.5 \mu \mathrm{m})$; conidial septa (1-3). Brown to black pycnidia appeared after 15 days of inoculation. In Septoria passerinii (Host - Hordeum sp.) conidial length varies $(37-57 \mu \mathrm{m})$; width (1.5-2 $\mu \mathrm{m})$; conidial septa (1-3); pyicnidia appears after 1 month and were dark brown and solitary turning black after 5 days. Septoria halophila (host - Hordeum glaucum) conidial length $(36-45 \mu \mathrm{m})$; width (1.5-2 $\mu \mathrm{m})$; septa (1-2). Pycnidia were mostly solitary, sometimes aggregated.

Various species of Septoria showed various morphometric specification along with morphotypes. The majority of fungal morphotypes occur in hyphae and yeast growth forms. In hyphae it produces pseudo hyphae which can withstand the environmental stresses and protect pathogen from physical barriers and colonies in the host issue. These morphotypes are used for pathogen to survive in biotic and abiotic stresses and may be itself very strong to survival in this drastic condition.

\section{Cultural variability}

Development of pycnidia or stroma-like structures by various isolates of $S$. tritici was tested on artificial media (Djerbi et al. 1974; Lee and Jones 1974; Weber
1922). Development of pycnidia is also tested on Czapek Dox-agar, Czapek Dox -V8 and plain V8 agar was tested by Cooke and Jones (1970) and Benedict (1971), consecutively. Semi synthetic media like water agar with plant material extracts was tested for in vitro formation of fructifications of Fusarium spp. and S. nodorum (Fisher et al. 1982). Insertion of wheat leaf extracts is reported to be beneficial to pycnidium formation by $S$. tritici (Pieroborn 1983; Zelikovitch and Eyal 1989).

Pycnidiospores helps for identification of Septoria. Pycnidia was not associated with any oozing surrounding its vicinity. These types of morphological structures are not true pycnidia and considered to be pseudopycnidia (Pierobom 1983; Djerbi et al. 1974). Pycnidia and pseudopycnidia are grouped into four different classes: absent, scarce, moderate and abundant. Cultural growth comes with yeast-like manner, intermediate, pinkish, smooth to scattered surfaced colonies and scarce mycelial growth at periphery. Intermediate cultural growth characterized with dark, smooth surface and extensive mycelial network at the periphery. Sometimes dark grayish colonies appear with slow growth and scattered colonial surface.

\section{Pathogenic variability}

Pathogenic variability varies from one host to other. Diverse species of Septoria attacked different cultivated and non cultivated crops in unique mechanistic way. Pathogenic variability mainly depends on its diseases development and based on is spore size. This hyphae is grows only from the tips and in some cases it show pseudo hyphae according to the environmental stress it depends. It is the one of the most common and serious widespread leaf-spotting fungi worldwide. The identification of the species is based on its host and its biogeography location. The genus includes more than 1000 published names of species and intra specific taxa. The fungal pathogenicity was cross checked in artificial conditions and grew in the green house in pots for 8-9 weeks which mostly depends on temperature and humidity range. Plants were inoculated through spraying of spore suspension method. Plants were incubated by placing the pots in trays that were partially placed with water. Symptoms were within consecutive days. Mechanistic approach of pathogenic variability 
Table 1: Detailed view of fungal pathogen species and its morphological characters

\begin{tabular}{|c|c|c|c|c|c|}
\hline Pathogen species & Host & $\begin{array}{l}\text { Length } \\
(\mu \mathrm{m})\end{array}$ & $\begin{array}{l}\text { Width } \\
\text { ( } \mu \mathrm{m})\end{array}$ & $\begin{array}{l}\text { Conidial } \\
\text { septa }\end{array}$ & Pycnidia (fruiting body colour) \\
\hline Septoria sp1 & Aegilops auschii & $18-37$ & $1-1.5$ & $1-3$ & $\begin{array}{l}\text { Dark brown usually solitary, sometimes } \\
\text { aggregation }\end{array}$ \\
\hline Septoria sp 2 & Lolium loliaceus & $20-46$ & $1-1.5$ & $1-2$ & Brown to black in colour \\
\hline Septoria passerinii & H.vulgare and H.distichon & $37-57$ & $1.5-2$ & $1-3$ & $\begin{array}{l}\text { Dark brown and solitary after } 5 \text { days } \\
\text { turns black }\end{array}$ \\
\hline Septoria tritici & $\begin{array}{l}\text { Ttiticum aestium, T.duram, } \\
\text { T.dicoecum E T.conpactum }\end{array}$ & $47-80$ & $1.5-2$ & $1-4$ & Brown in colour \\
\hline Septoria triseti & Phalaris parados & $19-40$ & $1-1.5$ & $0-3$ & No information yet. \\
\hline Septoria calamagrostidis & Avena ludoviciana & $33-65$ & $1-1.5$ & $3-4$ & Dark brown to black in colour \\
\hline
\end{tabular}

examined infection pattern, infection rate, attacking site and viability of regenerating unit. Even diversity is also found on infection and symptomatic site appearance. The pathogen spots size differ from different species in the same genera of Septoria where some species show moderate range of spot size and some species may show wide range in diameter $(\mu \mathrm{m})$.

\section{Life cycle pattern of Septoria sp.}

This fungal pathogen disease cycle begins with spore or conidia which are carried from infected plant to healthy plant through rain splashes and wind. These spores are deposited on the leaves of healthy plants and penetrate into it through external openings of leaves or through stomata directly. After penetration, disease symptoms can develop within 6 days. Without any direct penetration, Zymoseptoria tritici enter host cell through any mode of natural opening like stomata and completes its asexual life cycle (Dean et al. 2012; Rudd et al. 2015). It's apoplastic mode of colonization make it different from all other fungal pathogens which are invasive at the time of infection (Lee et al. 2014). When the humidity is more and temperature is $68-77^{0} \mathrm{~F}$, this pathogen can easily disseminate in or on contaminated seeds, insects, mechanical tools. This pathogen remains alive even the whole crop is harvested from the field and stay in dormant stage up to 2 years. Tan yellow to brown angular lesions of about 0.1 inch in diameter can be observed on the leaf. These lesions are containing grayish centers and are often dotted with small black fungal fruiting bodies (pycnidia), which contain spores (asexual spores). After 24 hours of infection, germination and hyphal branching of pycnidia spores can be observed. After 48 hours of infection, the spore count number increases facilitating the transfer of the infective propagules. The symptom mainly observed from older leaves to younger leaves. If the disease is in severe condition, the leaves become brown to necrotic and then wither off. Fruit fails to mature leading to yield loss of the crop. During the life cycle of fungal pathogen, it adopts many characters to withstand the biotic and abiotic stresses and make itself resistant to survive in the drastic conditions. Complete disease cycle of Septoria sp. represented through Fig. 3.

\section{Active biomolecular approach in host pathogenic interaction}

Tramesan is one of the effective component helps in synthesis of defense-related hormones, specificially JA, and several specific markers of plant defenses (PR1 and PR4 inter alia) etc. It was found effective after 48 hours of post inflectional treatment (Valeria et al. 2020). Mitogen-activated protein kinase MPK3 and the LysM receptor kinase CERK1 showed highest probable efficacy in host pathogen interaction (Arraiano and Brown, 2017) tough that is introduced by Tramesan and fungal pathogen infection. Simultaneously, MCA2, RBOH and PAL are overwhelming by other stress hormonal responses [auxin (-PIN2) and ABA (-TAS14)] (Ors et al. 2019). Aggregated pathogenesis related proteins regulated by SA (PR1 and PR9), or by JA (PR4) pathways (Tateda et al. 2014), and combining correlational approach. In case of SA-controlled genes, NPR1 is the most boosting activator and stimulus (Rawat et al. 2017). Few receptors act as 


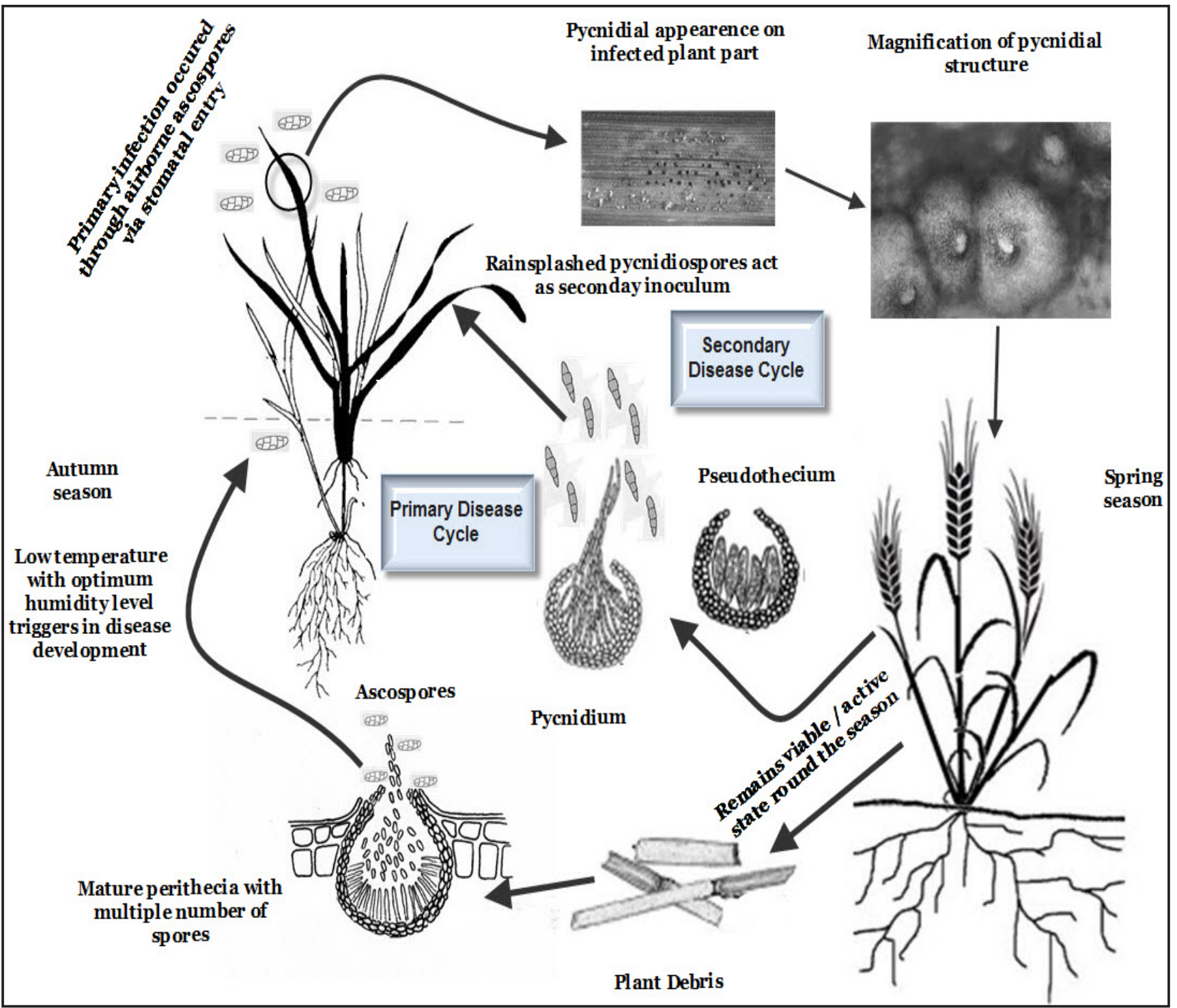

Fig. 3: Schematic representation of disease cycle of Septoria sp.

ligands of fungal glucans, and moderate various responses (such as innate immunity to cell death or symbiosis). Consecutive study comes out as wheat receptor kinase proteins putatively capable to bind with oligochitosan (Shen et al. 2018).

\section{Estimation of crop yield loss}

Septoria tritici was one of the serious and destructive fungal disease throughout the world, which mainly infects the foliage system of the plant. There are many reports of yield losses due to Septoria fungal pathogen in cereals and many wild grasses. The loss due to Septoria tritici on winter wheat was reported about 10.5- $44.6 \%$ in the region of USA. According to the research, the estimated loss is ranging from 10.5 to $27.6 \%$ during natural infection. In New
Zealand, it was observed that Septoria tritici infection was controlled by spraying Dithane (Zineb) in 14 days interval which resulted $10 \%$ increased yield in autumn-sown wheat crop. According to Weber, Septoria nodorum reported severe yield loss i.e. more than $50 \%$ in natural condition (Weber, 1922) while $45.5 \%$ of yield loss was observed when the fungi was inoculated at a spore concentration of above $10^{3}$ spores $/ \mathrm{ml}$.

\section{Epidimological perspective for wide versatility}

This fungus mainly spreads through air borne ascospores (Shaw and Royle 1987). Based on favorable temperature and alternate host, pycnidia can survive nearly 14 to 40 days. Conidia may be dispersed by rain splashes and easily travel 
up to $1 \mathrm{~m}$ radius. The infection may produce 50,000 to 5,00,000 conidia (Eyal 1999) and most of this spore are dispersed with in a circle of $0.5 \mathrm{~m}$ radius. Recently, one experiment conducted on the basis of the fungal growth which concluded that artificially grown pathogen was failed to establish under field conditions due to variations in temperature, relative humidity and rain splashes. Under artificial condition Secale cereale and Lolium rigidum is sensitive to pathogen Septoria tritici, but in the natural field conditions it is resistant to the pathogen (Haghdel and Banihashemi 2005).

Now a days, experiments are accomplished by using artificial conditions such as glass house which are favorable to conduct field trials in any season by creating proper temperature for the growth of plants. However, in one experiment Septoria calamagrostidis and Septoria triseti did not show any disease symptom on original host plants while in glass house conditions, it was difficult to identify the pycnidia and pycnidia spores enabling the infection.

\section{Management of Septoria diseases}

In the growing season, the Septoria leaf spot is spread from moderate to severe condition. This pathogen attack can be prevented in moderate stage by maintaining the good cultural practices.

\section{Cultural practices}

1. Avoid planting in the same space for at least 3 years as the organisms alive in the plant debris for 2 years. So, crop rotation is highly required.

2. Removal of infected and diseased leaves is very important.

3. Maintain the proper sanitation in the field and don't irrigate more to crops in evening time (temperature favor to disease spread) and avoid work in the field by using mechanical tools while field is in wet condition.

4. Removal of weeds and plant debris in the fields and in the bunds, which can set out alternate hosts for Septoria leaf pathogens.

5. Use of resistant varieties.

\section{Biological control}

1. The method is most useful to reduce the risk of fungicidal sprays.
2. Use of antagonistic micro-organisms is a very crucial approach in biological control. It helps to check the spread of primary inoculums, easily control the specific pathogen both in green house and field condition (Cook and Baker 1983; Blum et al. 1991).

\section{Chemical methods}

At the present days, the only way to control the pathogen effect and its severity is by spraying chemicals in the field. It protects the field in 1st stage of infection .i.e. when plants show moderate range of symptoms. According to Torriani and his coworkers (2015), Europe is spending one billion dollars in fungicide spray to control Septoria but it was observed that these fungicides are losing efficacy as Zymoseptoria tritici were gaining resistant against wide group of fungicide.

1. In present days, seed dressing fungicide is also available in the market to reduce the impact of pathogen towards crop .e.g. Fluquinconazole and Silthiofrans.

2. When weather condition is favorable for disease spread and survival of pathogen, the regular sprays of fungicides are practiced to control Septoria leaf spot. This chemical practice is very much effective compared to cultural and mechanical method.

Most effective fungicides are Mancozeb, Copper oxychloride, Chlorothalonils and the mixture of Strobilurin and Flint. Regular usage of fungicides leads to resistant of fungal pathogen against the specific fungicide which was proved in Ireland in 2001 and these types of cases are reported in many areas like UK, France and Belgium in 2002. The occurrence of mutation in the DNA of fungus makes them resistant to spray application of fungicides leading to spread the disease very quickly throughout the world. Recent studies showed that Septoria spp. are sensitive to triazoles group of chemicals. Therefore, it is essential to choose the alternate chemicals belonging to other group which can prevent the resistance.

\section{DISCUSSION}

The article gives a brief explanation of the most notorious fungal pathogen Septoria and its history, host specificity, morphological and pathological 
characters and its management. Septoria spp. is associated with many plants such as Tritucum aestivum, Aegilops tauschii, Phalaris minor, Lolium loiaceum etc. and are known as primary host for Septoria spp. Several strains of Septoria spp. are emerged due to the mutations in the DNA and show wide variability in its morphological as well as pathological characters. In Septoria, different morphotypes have its different roles during hostpathogen interaction to protect themselves from environmental stresses. The disease cycle begins with fungal spores (conidia) which is transmitted through wind and deposited directly in the healthy leaves followed by penetrating in to leaves through natural openings, and through stomata. The symptoms can appear within 6 days of infection. Pycnidia are observed to form in the leaves tissues which produce brown to black fruiting bodies showing yellowish to brown color angular lesions with grey centered. The symptoms and the spore size vary from species to species. Under the microscope, the mycelia pigmentation, sporulation, conidial septa number are observed.

When the spots are numerous in number, it gradually increases the count which leads to disease severity. These species are mainly grown in extended periods of warm, wet and humid conditions but temperature and moisture content vary from species to species. In many experiments, scientists reported that Septoria spp. failed to show symptoms in artificial conditions while in natural field conditions, symptoms are exhibited by the pathogen. This is due to the variations in the temperature and relative humidity. Zymoseptoria tritici populations are highly diversified which ultimately resulted mixed reproductive system, major gene flow with huge population sizes (Yates et al. 2019; Zhan et al. 2003). The rapid change of virulence against resistant varieties (McDonald and Mundt 2016) and wide range of fungicides (Estep et al. 2015; Hayes et al. 2016) is highly dependent on these characters.

This pathogen was reported to cause huge economic losses up to 35- 65\%. According to Caldwell and Narveas (1960), $10.5 \%$ to $44.6 \%$ loss occurs due to artificial infection while in natural infection $10.5 \%$ $27.6 \%$ losses were recorded. This notorious pathogen can be controlled only by following good ecofriendly practices like proper crop rotations, field sanitation, irrigation management etc. Biological methods such as application of microbial antagonists are also used widely to control the pathogen population. The chemical methods are most useful to eradicate the disease. Though recently Ministry of agriculture and farmers welfare, Govt. of India, notified through Govt. Gazette notification [S.O. 1512(E) dated $14^{\text {th }}$ May, 2020] of list of prohibited insecticides which enlisted acephate, atrazine, benfuracarb, butachlor, captan, carbendazim, carbofuran, chloropyriphos, 2,4 D, deltamethrin, dicofol, dimethoate, dinocap, diuron, malathion, mancozeb, methomyl, monocrotophos, oxyfluorfen, pendimethalin, quinaphos, sulfosulfuron, thiodicarb, thiophanat emethyl, thiram, zineb, ziram etc. So, marketing or business exposure or promotions of those agrochemicals are restricted. Dithane (Zineb) is most effective fungicide to control the pathogen population. After 14 days of fungicide application, diseases control was reported to $35 \%$ while yield was increased $10 \%$. But every time when we go through chemical method we must be more responsible to our soil and environment to promote sustainable agriculture for future. Among all the methods, Integrated crop disease management was proved one of the best strategies to control the severe foliar disease with eco-friendly approach.

\section{REFERENCES}

Arraiano, L.S. and Brown, J.K.M. 2017. Sources of resistance and susceptibility to Septoria tritici blotch of wheat. Mol. Plant Pathol., 18: 276-292.

Benedict, W.G. 1971. Differential effect of light intensity on the infection of wheat by Septoria tritici Desm. under controlled environmental conditions. Physiological Plant Pathology, 1: 55-66.

Blum, L.E.B. and Lin, M.T. 1991. Potencial de Trichoderma e Pseudomonas fluorescentes para o controle do tombamento de mudas causado por Cylindrocladium spp. Fitopatologia Brasileira, Brasília, 16(1): 71-74.

Caldwell, R.M. and Narvaes, I. 1960. Losses to winter wheat from infection by Septoria tritici. Phytopathology, 50: 630.

Cooke, B.M. and Jones, D.G. 1970. The effect of near-ultraviolet irradiation and agar medium on the sporulation of Septoria nodorum and S. tritici. Transactions of the British Mycological Society, 54: 221-226.

Chakraborty, S. andNewton, A.C. 2011. Climate change, plant diseases and food security: an overview. Plant Pathol. 60: $2-14$.

Cook, R.J. and Baker, K.F. 1983. The nature and practice of biological control of plant pathogens. St Paul: APS, pp. 539. 
Dean, R., Van-Kan, J.A.L., Pretorius, Z.A., Hammond-Kosack, K.E., Di Pietro, A., Spanu, P.D., Rudd, J.J., Dickman, M., Kahmann, R. and Ellis, J. et al. 2012. The top 10 fungal pathogens in molecular plant pathology. Mol. Plant Pathol., 13: 414-430.

Djerbi, M., Kerlan, C. and Bompeix, G. 1974. Observations sur la morphogen se et la cytology des fructifications du Septoria tritici Rob. et Desm. Annales de l'Institut National de la Recherche Agronomique de Tunisie, 47(3): 56.

Estep, L.K., Torriani, S.F.F. and Zala, M. et al. 2015. Emergence and early evolution of fungicide resistance in North American populations of Zymoseptoria tritici. Plant Pathology, 64(4): 961-971.

Eyal, Z. 1999. The Septoria/Stagonospora blotch diseases of wheat: past, present, and future. In: M. van Ginkel, A. McNabb and J. Krupinsky (eds): Septoria and Stagonospora diseases of cereals: a compilation of global research. CIMMYT, Mexico, pp. 177-182.

Fisher, M.C., Henk, D.A., Briggs, C.J., Brownstein, J.S., Madoff, L.C., McCraw, S.L. and Gurr, S.J. 2012. Emerging fungal threats to animal, plant and ecosystem health. Nature. 484: 186-194.

Fisher, N.L., Burgess, L.W., Toussoun, T.A. and Nelson, R.E. 1982. Carnation leaves as a substrate and for preserving cultures of Fusarium species. Phytopathology, 72: 151-153.

Haghdel, M. and Banihashemi, Z. 2005. Survival and host range of Mycosphaerella graminicola the causal agent of Septoria leaf blotch of wheat. Iranian Journal of Plant Pathology, 41: 613-630.

Hayes, L.E., Sackett, K.E., Anderson, N.P., Flowers, M.D. and Mundt, C.C. 2016. Evidence of selection for fungicide resistance in Zymoseptoria tritici populations on wheat in western Oregon. Plant Disease, 100(2): 483-489.

Hilu, H.M. and Bever, W.M. 1957. Inoculation, oversummering and suscept-pathogen relationship of Septoria tritici on Triticum species. Phytopathology, 47: 474-480.

Holliday, P. 1989. A Dictionary of Plant Pathology. Cambridge University Press, Cambridge, UK, pp. 560.

Kovalenko, S.N. 1976. The role of the dates of showing of winter wheat in the reduction of the development of Septoria leaf spot under the conditions of the Forest-steppe in the USSR. Nauch Trudy USKA, 161: 123-125.

Lee, N.P. and Jones, D.G. 1974. Rapid method for spore production in three Septoria species. Transactions of the British Mycological Society, 62: 208-211.

Lee, W.S., Rudd, J.J., Hammond-Kosack, K.E. and Kanyuka, K. 2014. Mycosphaerella graminicola LysM effector-mediated stealth pathogenesis subverts recognition through both CERK1 and CEBiP homologues in wheat. Mol. Plant Microbe Interact., 27: 236-243.

McDonald, B.A. and Mundt, C.C. 2016. How knowledge of pathogen population biology informs management of Septoria tritici blotch. Phytopathology, 106(9): 948-955.

Ors, M., Randoux, B., Siah, A., Couleaud, G., Maumené, C., Sahmer, K., Reignault, P., Halama, P. and Selim, S.A. 2019.
Plant nutrient-and microbial protein-based resistance inducer elicits wheat cultivar-dependent resistance against Zymoseptoria tritici. Phytopathology, 109: 2033-2045.

Pierobom, C.R. 1983. Studies on pycnidial and ascocarpic fungi which cause leaf spots in wheat in Washington. Ph.D. Thesis, Washington State University, Pullman, Washington.

Priest, M.J. 2006. Fungi of Australia: Septoria. ABRS, Canberra, CSIRO Publishing, Melbourne, Australia, pp. 268.

Rawat, S., Ali, S., Mittra, B.. and Grover, A. 2017. Expression analysis of chitinase upon challenge inoculation to Alternaria wounding and defense inducers in Brassica juncea. Biotechnol. Rep., 13: 72-79.

Rudd, J.J., Kanyuka, K.. and Hassani-Pak, K et al. 2015. Transcriptome and metabolite profiling of the infection cycle of Zymoseptoria tritici on wheat reveals a biphasic interaction with plant immunity involving differential pathogen chromosomal contributions and a variation on the hemibiotrophic lifestyle definition. Plant physiology, 167: 1158-1185.

Savary, S. , Willocquet, L., Pethybridge, S.J., Esker, P. and McRoberts, N. and Nelson, A. 2019. The global burden of pathogens and pests on major food crops. Nature Ecology E Evolution, 3(3): 430-439.

Shaw, M.W. and Royle, D.J. 1987. Spatial distributions of Septoria nodorum and S. tritici within crops of winter wheat. Plant Pathology, 36: 84-94.

Shen, Q., Liu, L., Wang, L. and Wang, Q. 2018. Indole primes plant defense against necrotrophic fungal pathogen infection. PLoS ONE, 13(11): e0207607.

Shirin, S., Mohammad, R., Heshmatolah, A., Rasoul, Z. and Hassan-Reza, E. 2009. Studies on the host range of Septoria species on cereals and some wild grasses in Iran. Phytopathol. Mediterr., 48: 422-429.

Sprague, R. 1950. Some leaf spot fungi on western Gramineae. Mycologia, 42: 758-777.

Tateda, C., Zhang, Z., Shrestha, J., Jelenska, J., Chinchilla, D. and Greenberg, J.T. 2014. Salicylic acid regulates Arabidopsis microbial pattern receptor kinase levels and signaling. Plant Cell, 26: 4171-4187.

Tokeshi, H. and Carvalho, P.C.T. 1980. doenças do tomateiro - Lycopersicum esculentum mill. In: galli, f. Manual de fitopatologia - doenças das plantas cultivadas. São paulo: agronômica ceres, 2(35): 511-532.

Torriani, S.F.F., Melichar, J.P.E., Mills, C., Pain, N., Sierotzki, H. and Courbot, M. 2015. Zymoseptoria tritici: a major threat to wheat production, integrated approaches to control. Fungal Genetics and Biology, 79: 8-12.

Valeria, S., Chiara, P., Valentina, F., Marzia, B., Slaven, Z., Fabrizio, Q., Mauro, F., Marco, Z., Babak, M., Massimo, R. and Angela L. 2020. Tramesan elicits durum wheat defense against the Septoria disease complex. Biomolecules, 10: 608 .

Weber, G.E.1922. Septoria diseases of wheat. Phytopathology, 12: 537-585. 
Yates, S., Mikaberidze, A. and Krattinger, S.G. et al. 2019. Precision Phenotyping Reveals Novel Loci for Quantitative Resistance to Septoria tritici Blotch. Plant phenomics, 1: 1-11.

Zelikovitch, N. and Eyal, Z. 1989. Maintenance of virulence of Septoria tritici cultures. Mycological Research, 92: 361-364.
Zhan, J., Pettway, R.E. and McDonald, B.A. 2003. The global genetic structure of the wheat pathogen Mycosphaerella graminicola is characterized by high nuclear diversity, low mitochondrial diversity, regular recombination, and gene flow. Fungal Genetics and Biology, 38(3): 286-297. 